\title{
Penggunaan Media Kartu Domino Dalam Meningkatkan Keterampilan Operasi Hitung Pada Siswa Kelas III SDN 240 Harue Kabupaten Bulukumba
}

\author{
Dahlan \\ Pengawas SD, Dinas Pendidikan Kabupaten Bulukumba \\ malyoboro@gmail.com
}

\begin{abstract}
ABSTRAK
Penelitian ini bertujuan untuk meminimalkan kesalahan-kesalahan pada pembelajaran, meningkatkan prestasi belajar Matematika siswa Kelas III khususnya pada Kompetensi Dasar Operasi Hitung Campuran, dan melatih siswa agar terampil menggunakan media. Manfaat penelitian ini bagi guru yakni terampil dalam menggunakan alat peraga/media Kartu Domino dan menerapkan metode diskusi. Bagi siswa untuk meningkatkan kemampuanya menerima pelajaran Matematika pada Kompetensi Dasar Operasi Hitung Campuran. Untuk menyelesaikan masalah yang timbul sebagai upaya pemecahanya adalah dilaksanakan penelitian tindakan kelas yang dibagi dalam dua siklus.Simpulan yang diperoleh setelah penelitian ini adalah dengan menggunakan alat peraga kongkrit/media Kartu Domino dan metode diskusi hasil belajar siswa dapat meningkat.
\end{abstract}

\section{Kata Kunci: Keterampilan Operasi Hitung, Media Kartu Domino}

\section{PENDAHULUAN}

Keberhasilan siswa di dalam proses belajar menjadi dambaan bagi setiap guru. Oleh karena itu, berbagai usaha dilakukan untuk meningkatkan mutu pembelajaran. Usaha yang dapat dilakukan untuk itu adalah dengan menyediakan sarana dan prasarana yang dibutuhkan sekolah serta meningkatkan peran guru. Karena dengan ditingkatkannya peran guru dan ketersediaan sarana dan prasarana yang memadai, diharapkan akan dapat meningkatkan hasil belajar siswa.

Melihat hasil evaluasi pelajaran Matematika pada materi Operasi Hitung di kelas III SD Negeri 240 Harue Kecamatan Bulukumpa Kabupaten Bulukumba dari siswa sebanyak 11 anak, baru 3 siswa atau 27,27 yang dapat melakukan operasi hitung 8 siswa atau $72,72 \%$ belum tuntas. Siswa dinyatakan tuntas apabila mendapat nilai $70 \%$ ke atas.

Sudah cukup lama kita semua terbenam dalam pembelajaran matematika yang bagi banyak orang terasa asing, formal dan hanya bermain angka atau symbol yang sulit dan serba tak berarti, bahkan tidak sedikit yang merasa katakutan untuk menghadapi pelajaran matematika. Sejarah tumbuhnya matematika di berbagai belahan bumi karena adanya tantangan hidup yang dihadapi manusia di wilayah itu. Hal ini dapat diartikan bahwa matematika tumbuh antara lain karena diperlukan untuk mengatasi tantangan hidup itu dikutip dari Soedjadi (2007). Melalui komunikasi antar manusia antar bangsa, matematika berkembang menjadi lebih luas, lebih umum, lebih berguna bagi kehidupann manusia.

Guru dan orang tua murid perlu benarbenar menyadari bahwa anak didik umumnya adalah manusia kecil yang tengah tumbuh berkembang semua organ dirinya. Semua orang itu ada, utuh dan lengkap adanya. Karunia yang luar biasa besarnya dari Sang Pencipta untuk disemai tumbuhkan dalam lingkungannya, oleh lingkungannya yang akhirnya memang untuk lingkungannya. Pembelajaran matematika di sekolah tidak langsung menggunakan objek-objek abstrak, namun dapat dan perlu dibantu dengan menggunakan objek-objek yang konkret sebagai jembatan untuk memahami matematika yang objeknya abstrak itu. Guru dan orang tua murid perlu percaya bahwa anak didiknya memiliki daya atau potensi yang perlu bantuan atau dorongan untuk berkembang sesuai dengan kodratnya. Bukan untuk dipaksa dikembangkan, diperintah, dan menjadi pak turut, anak didik memerlukan kesempatan untuk merenung, mengenali, berpikir, merasakan dan mencoba-coba melakukan sesuatu.

Pengalaman itu akan sangat membantu perkembangan potensinya kearah yang bermanfaat di masa depan. Naluri hidup 
seorang anak memang selalu ingin tahu, ingin tahu apa saja, apa yang sedang dia hadapi, apa sebab demikian, mengapa begitu mengapa tidak begini. Penyaluran naluri alamiah itu secara tepat, tanpa memberi tekanan apapun, akan memberi keleluasan perkembangan yang dapat optimal dan memang ia membutuhkan. Anak didik itu hanya memerlukan pengamanan dirinya sewaktu diperlukan, selagi perkembangan pribadinya belum sanggup bersikap mandiri.

Potensi untuk memahami sesuatu yang abstrak ataupun yang konkret sebenarnya ada pada diri anak didik, tetapi perkembangan anak itu cenderung terlebih dahulu mudah memahami yang konkret daripada yang abstrak. Hal ini sesuai dengan perkembangan kemampuan panca inderanya. Selaras dengan perkembangan usia anak, berkembang juga semua potensi yang ada pada dirinya. Potensi itulah yang amat perlu dipahami seorang guru dan orang tua, agar dapat dengan "tepat" memilih materi ajar ataupun pengetahuan lain yang dipandang perlu diketahui atau dipahami anak didik. Pemaksaan atau pemberian suatu materi ajar atau pengetahuan yang tidak tepat akan memungkinkan terjadinya "kelelahan" anak didik sewaktu masih muda.

Penggunaan media pembelajaran dapat membantu pengajar dalam menyampaikan materi sehingga para siswa lebih mudah memahami materi yang akan diajarkan, sehingga dapat meningkatkan prestasi belajar siswa. Melalui perantaraan media yang menarik, siswa akan lebih mudah untuk menangkap materi pelajaran, hal ini akan berdampak positif terhadap prestasi belajar siswa. Ketidakjelasan dan kerumitan bahan pelajaran yang akan disampaikan, dapat dipermudah dengan menghadirkan media sebagai alat bantu mengajar. Kehadiran media pula diharapkan dapat mewakili yang kurang mampu dijabarkan oleh komunikator (guru) melalui kata-kata atau kalimat.

Permainan Domat (Domino Matematika), sama halnya dengan domino biasa, namun media atau alat peraga domino ini dapat dimainkan oleh 2-8 orang, bedanya terletak pada kartu yang digunakan serta tata cara menurunukan kartu. Jika kartu dimono biasa berisi kumpulan atau urutan angka-angka yang diwakili oleh lingkaran-lingkaran dengan bilangan terendah nol dan bilangan tertinggi adalah enam. Kalau pada permainan domino ini diwakali oleh lambang bilangan 1-9 dengan jumlah kartu sebanyak empat puluh lima (45) lembar
Hasil evaluasi mata pelajaran Matematika kelas III semester I dengan materi Operasi Hitungpada SD Negeri 240 Harue menunjukkan bahwa dari 11 siswa hanya ada 3 siswa yang mendapat nilai baik, yang berarti tingkat batas ketuntasannya hanya $27,27 \%$. Penulis kemudian meminta bantuan teman sejawat untuk mengidentifikasi kekurangan yang menjadi penyebab ketidakberhasilan proses pembelajaran yang telah berlangsung.

\section{METODE PENELITIAN}

Penelitian ini adalah penelitian tindakan kelas (PTK). Subyek dalam PTK ini adalah siswa kelas III SDN 240 Harue tahun pelajaran 2016/2017. Penentuan kelas ini dilaksanakan peneliti berdasarkan hasil investigasi terhadap kelas yang diajar oleh peneliti dan kelas ini dipandang sangat diperlukan adanya peningkatan keterampilan operasi hitung dan kemampuan bernalar siswa, khususnya pada mata pelajaran matematika. Penelitian ini dilaksanakan selama dua bulan sejak mulai kegiatan perencanaan, persiapan hingga pelaksanaan tindakan, analisis data, dan penyusunan laporan PTK, dengan rincian sebagai berikut

a. Refleksi awal dari hasil investigasi terhadap kelas yang menjadi subyek PTK. Kegiatan ini peneliti laksanakan melalui observasi dalam pembelajaran, wawancara dan angket kegiatan ini dilaksanakan mulai minggu kedua bulan Juli 2016.

b. Siklus I dilaksanakan pada tanggal 28 Juli 2016 sampai dengan 8 Agustus 2016 dengan rincian: tanggal 30 Juli 2016 diadakan pertemuan pertama yang diawali dengan pretes siklus I, tanggal 4 Agustus 2016 diadakan pertemuan kedua, dan tanggal 8 Agustus 2016 pertemuan ketiga, dan diadakan postes siklus I.

c. Siklus II dilaksanakan pada tanggal 20 Agustus 2016 sampai dengan tanggal 31 Agustus 2016 dengan rincian: tanggal 22 Agustus 2016 pertemuan pertama, tanggal 25 Agustus 2016 pertemuan kedua, tanggal 29 Agustus 2016 pertemuan ke tiga, dan pelaksanaan postes siklus II.

d. Analisis data dilaksanakan mulai tanggal 1 September 2016 s/d tanggal 19 September 2016

e. Pelaporan disusun pada minggu kedua dan ketiga bulan September 2016

Indikator keberhasilan dalam tindakan kelas ini dapat dijelaskan dalam tabel 1 berikut ini. 
Tabel 1. Jenis Data, Instrumen Data, Kriteria Keberhasilan Tindakan Pengajaran

\begin{tabular}{|c|c|c|c|}
\hline No & Jenis Data & Instrumen Data & Indikator Keberhasilan \\
\hline 1. & $\begin{array}{l}\text { Aktivitas } \\
\text { siswa }\end{array}$ & $\begin{array}{l}\text { a. Penyelesaian LKS, } \\
\text { laporan hasil } \\
\text { permaian Domat. }\end{array}$ & $\begin{array}{l}\text { Nilai hasil permaian Domat game, menyusun } \\
\text { laporan observasi mencapai } \geq 70 \text {, dan jumlah } \\
\text { siswa yang memperoleh skor } \geq 70 \text { sebanyak } \\
\geq 75 \% \text { serta meningkat dari siklus ke siklus }\end{array}$ \\
\hline 2. & $\begin{array}{l}\text { Motivasi } \\
\text { belajar } \\
\text { siswa }\end{array}$ & $\begin{array}{l}\text { b. Lembar observasi } \\
\text { proses belajar } \\
\text { (keterampilan } \\
\text { kognitif, } \\
\text { psikomotorik dan } \\
\text { afektif) } \\
\text { c. Kuisioner motivasi } \\
\text { belajar siswa }\end{array}$ & $\begin{array}{l}\text { Skor kelompok mencapai } \geq 70, \text { dan } \\
\text { meningkat dari siklus ke siklus }\end{array}$ \\
\hline 3 & $\begin{array}{l}\text { Penilaian } \\
\text { hasil belajar }\end{array}$ & d. Pretesst dan postes & Hasil postest $>75 \%$ \\
\hline
\end{tabular}

\section{HASIL \& PEMBAHASAN}

Pada bagian ini peneliti memaparkan mengenai kondisi lapangan pada saat tindakan pembelajaran berlangsung, yaitu merekam semua aspek yang terjadi pada waktu penelitian. Supaya situasi pembelajaran dapat pembaca ikuti secara utuh, maka peneliti memaparkan semua proses yang terjadi selama berlangsungnya pembelajaran, mulai dari kegiatan awal hingga peneliti menutup pembelajaran dari masing-masing pertemuan. Paparannya sebagai berikut:

\section{A. Siklus 1}

\section{Pelaksanaan dan Hasil siklus I}

Pembelajaran siklus 1 selama tiga kali pertemuan dan satu kali pertemuan untuk postes. Pertemuan pertama diawali dengan pembuka pelajaran dan melakukan pengapabsenan siswa yang tidak hadir. Pada pertemuan ini jumlah siswa yang hadir 11 orang. Guru menyampaikan informasi tentang Kompetensi Dasar "Melakukan Operasi Hitung Bilangan Campuran". Dalam kesempatan ini pembelajaran dilakukan melalui informasi dan tanya jawab antara guru dan siswa, guru banyak mengomentarkan masalah-masalah yang kontekstual untuk dipecahakn oleh siswa. Guru melakukan penilaian terhadap aktivitas siswa dalam proses pembelajaran ini dengan menggunakan lembar pengamatan dalam proses pembelajaran (terlampir). Pada pertemuan pertama guru juga menginformasikan serta memberi motivasi bahwa pembelajaran tentang Melakukan Operasi Hitung Bilangan Campuran, tidak hanya dilakukan secara teoritis saja, tetapi perlu mendapat pengalaman langsung dari permaian Domat. Siswa perlu memiliki kemampuan untuk mengkonstruksi sendiri berdasarkan pengetahuan dan pengalamannya dalam permaian Domat tersebut.

Pada pertemuan kedua, pembelajaran dilaksanakan pada jam 08.00 - 09.15, dalam kesempatan ini pembelajaran difokuskan pada penguasaan operasi hitung dengan cara malakukan permainan Domat.

Dalam melaksanakan diskusi observasi tentang Melakukan Operasi Hitung Bilangan Campuran. Tugas masing masing siswa adalah bermaian Domat dalam kelompoknya masing-masing dangan hasil sebagai berikut :

a. Kelompok Perkalian yakni:

Tabel 2. Daftar Hasil Permainan Domat Kelompok Perkalian Siklus 1

\begin{tabular}{|c|c|c|c|c|}
\hline \multirow{2}{*}{ No } & \multirow{2}{*}{ Nama Siswa } & \multicolumn{2}{|c|}{ Hasil } & \multirow{2}{*}{ Keterangan } \\
\hline & & Bintang & Nilai Kartu & \\
\hline 1 & MUH. TASBI & - & 43 & Peringkat V \\
\hline 2 & KIAN FEBRIAN & - & 52 & Peringkat VI \\
\hline 3 & AHMAD RASUL FIRDAUS & 药 & 7 & Peringkat I \\
\hline 4 & FAISAL & $\pi^{2}$ & 18 & Peringkat II \\
\hline 5 & MUH. CIPUTRA.S & ये & 21 & Peringkat III \\
\hline 6 & MUH. IKRAM & - & 39 & Peringkat IV \\
\hline
\end{tabular}

Berdasarkan hasil permainan Domat untuk kelompok perkalian yang dilaksanakan sebanyak satu kali putaran dengan empat kali game, maka pada skor akhir dijelaskan bahwa; 
siswa yang bernama Ahmad Rasul Firdaus memperoleh dua bintang ( pemain terbaik pertama dan nilai kartu tujuh maksudnya adalah jumlah nilai yang tertinggal pada saat perminan berlangsung. Faisal dan Cifutra masing-masing mendapat satu bintang, dengan nilai kartu 18 dan 21 sementara Muh. Tasbi, Kian Febrian dan Muh. Ikram tidak mendapat bintang. Artinya ketiga siswa tersebut pernah menutup game lebih awal

b. Kelompok Pembagian yakni:

Tabel 3. Hasil Permainan Domat Kelompok Pembagian Siklus 1

\begin{tabular}{|c|c|c|c|c|}
\hline \multirow{2}{*}{ No } & \multirow{2}{*}{ Nama Siswa } & \multicolumn{2}{|c|}{ Hasil } & \multirow{2}{*}{ Keterangar } \\
\hline & & Bintang & Nilai Kartu & \\
\hline 1 & FEBRIANTI & - & 47 & Peringkat V \\
\hline 2 & NADIRA & 药 & 33 & Peringkat III \\
\hline 3 & AVIRLY TRI PUTRI & 它 & 39 & Peringkat IV \\
\hline 4 & ANDINI MIFTAHUL & $\sum$ & 29 & Peringkat II \\
\hline 5 & EVI MEIRANI & $\hat{2}$ & 23 & Peringkat I \\
\hline
\end{tabular}

Berdasarkan hasil permainan Domat untuk kelompok pembagian yang dilaksanakan sebanyak satu kali putaran dengan empat kali game, maka pada skor akhir dijelaskan bahwa; ada empat siswa yang mendapat masingmasing satu bintang ( pembagian ini kemampuan siswa berimbang maka yang membedakan skor akhir untuk penentuan peringkat adalah jumlah point hasil akumulasi kartu yakni; Evi Meirani skor akumulasi 23, Andini Miftahul skor akumulasi 29, Nadira skor akumulasi 33, dan Avirly Tri Putri skor akumulasi 39.

\section{Refleksi siklus I}

Kelebihan-kelebihan yang ditemukan selama melaksanakan tindakan melalui pembelajaran dengan permaian Domat pada Kompetensi Dasar "Melakukan Operasi Hitung Campuran" digunakan oleh peneliti untuk dipertahankan dan dikembangkan. Sebaliknya kelemahan yang muncul dari pembelajaran tersebut di atas, digunakan oleh peneliti sebagai bahan refleksi dan upaya perbaikan pada pertemuan berikutnya dalam siklus kedua. Paparan hasil refleksi dapat dijabarkan sebagai berikut:

1). Partisipasi siswa saat pembelajaran sudah mulai nampak jika dibandingkan sebelum diadakan PTK.

2). Siswa semakin termotivasi untuk berbicara

3). Siswa nampak bergembira selama mengikuti pembelajaran. Kegembiraan ini berdampak kepada semangat belajar siswa, sehingga hasil postesnya meningkat dari pretes (rata-rata pretes 52 meningkat menjadi rata - rata postes 79,5 ).

4). Upaya peneliti memfasilitasi berlangsungnya PTK cukup bagus. Hal ini nampak dari alat-alat yang tersedia selama berlangsungnya tindakan (ada laptop, LCD, Kartu Domat)

5). Guru sebagai peneliti telah berusaha memperbaiki kinerjanya

6). Guru sebagai peneliti telah berupaya memberi motivasi yang cukup bermakna bagi siswa.

9). Peneliti selalu mengadakan diskusi dengan para observer di akhir pembelajaran pada setiap pertemuan.

Berdasarkan analisa data dan kegiatan pembelajaran selama pelaksanaan PTK maka dapat disimpulkan bahwa Permainan Domat sebagai upaya meningkatkan motivasi belajar siswa pada kompetensi dasar "melakukan operasi hitung bilangan campuran" meningkat, sehingga adanya upaya meningkatkan lagi motivasi belajar siswa melalui tindakan siklus ke II.

\section{B. Siklus 2}

\section{Pelaksanaan dan Hasil siklus 2}

Pembelajaran siklus 2 selama tiga kali pertemuan dan satu kali pertemuan untuk postes. Pertemuan pertama dilaksanakan pada tanggal 20 Agustus 2016 kegiatan diawali dengan pembuka pelajaran dan melakukan pengapabsenan siswa yang tidak hadir. Pada pertemuan ini jumlah siswa yang hadir 11 orang. Guru menyampaikan informasi tentang Kompetensi Dasar "Melakukan Operasi Hitung Bilangan Campuran". Dalam kesempatan ini pembelajaran dilakukan melalui informasi dan tanya jawab antara guru dan siswa, guru banyak mengomentarkan masalah-masalah yang ditemukan pada siklus 1 untuk diperbaiki pada kegiatan siklus 2 oleh siswa. Guru melakukan penilaian terhadap aktivitas siswa dalam proses pembelajaran ini dengan menggunakan lembar pengamatan dalam proses pembelajaran (terlampir). Pada 
pertemuan pertama guru juga menginformasikan serta memberi motivasi bahwa pembelajaran tentang Melakukan Operasi Hitung Bilangan Campuran, melalui permainan Domat pada siklus 1 masih terdapat kekurangan dan hambatan untuk selanjtnya diperbaiki pada siklus 2 dengan trik-trik khusus untuk menurunkan setiap kartu yakni memperhatikan nilai kartu tersebut. Siswa perlu memiliki kemampuan untuk mengkonstruksi sendiri berdasarkan pengetahuan dan pengalamannya dalam permainan Domat pada siklus 1. Pada pertemuan kedua pembelajaran dilaksanakan pada jam 08.00 - 09.15, dalam kesempatan ini pembelajaran difokuskan pada teknik menurunkan kartu yakni; jika terdapat kartu yang hasil operasinya sama maka yang diutamakan untuk diturunkan lebih awal adalah jumlah point tertinggi. Dalam melaksanakan diskusi observasi tentang Melakukan Operasi Hitung Bilangan Campuran. Tugas masing masing siswa adalah bermain Domat dalam kelompoknya masing-masing dangan hasil sebagai berikut:

a. Kelompok Perkalian yakni:

Tabel 4. Daftar Hasil Permaian Domat Kelompok Perkalian Siklus 2

\begin{tabular}{|c|c|c|c|c|}
\hline \multirow{2}{*}{ No } & \multirow{2}{*}{ Nama Siswa } & \multicolumn{2}{|c|}{ Hasil } & \multirow{2}{*}{ Keterangan } \\
\hline & & Bintang & Nilai Kartu & \\
\hline 1 & MUH. TASBI & - & 37 & Peringkat VI \\
\hline 2 & KIAN FEBRIAN & $\sum^{n}$ & 29 & Peringkat IV \\
\hline 3 & AHMAD RASUL FIRDAUS & $\sum$ & 13 & Peringkat I \\
\hline 4 & FAISAL & ז̧s & 17 & Peringkat II \\
\hline 5 & MUH. CIPUTRA.S & 产 & 21 & Peringkat III \\
\hline 6 & MUH. IKRAM & - & 35 & Peringkat V \\
\hline
\end{tabular}

Berdasarkan hasil permainan Domat untuk kelompok perkalian yang dilaksanakan sebanyak satu kali putaran dengan empat kali game, maka pada skor akhir dijelaskan bahwa; siswa yang beșama Ahmad Rasul Firdaus memperoleh satu bintang ( ), sebagai pemain terbaik pertama dan nilai kartu 13 maksudnya adalah jumlah nilai yang tertinggal pada saat

Tabel 5. Daftar Hasil Permainan Domat Kelompok Pembagian Siklus 2

\begin{tabular}{|c|c|c|c|c|}
\hline \multirow{2}{*}{ No } & \multirow{2}{*}{ Nama Siswa } & \multicolumn{2}{|c|}{ Hasil } & \multirow{2}{*}{ Keterangan } \\
\hline & & Bintang & Nilai Kartu & \\
\hline 1 & FEBRIANTI & - & 30 & Peringkat IV \\
\hline 2 & NADIRA & 药 & 17 & Peringkat II \\
\hline 3 & AVIRLY TRI PUTRI & 尔 & 25 & Peringkat III \\
\hline 4 & ANDINI MIFTAHUL & - & 38 & Peringkat $\mathrm{V}$ \\
\hline & EVI MEIRANI & گr & 8 & Peringkat I \\
\hline
\end{tabular}

Berdasarkan tabel 8 hasil permainan Domat untuk kelompok pembagian yang dilaksanakan sebanyak satu kali putaran dengan empat kali game, maka pada skor akhir dijelaskan bahwa; siswa yang bernama Evi Meirani mendapat dau bintang (2) dengan nilai kartu 8 sebagai pemain terbaik pertama. Sedangkan siswa yang bernama Nadira dan Avirly Tri Putri pada peringkat kedua dan ketiga dengan perolehan masing-masing satu bintang ( ) dengan nilai kartu 17 dan 25 .

\section{Refleksi siklus 2}

Kelebihan-kelebihan yang ditemukan selama melaksanakan tindakan melalui perminanan berlangsung. Faisal dan Cifutra, serta Kian Febrian masing-masing mendapat satu bintang, dengan nilai kartu 17 dan 21 Kian Febrian nilai kartu 29 dan Muh. Ikram tidak mendapat bintang.

b. Kelompok Pembagian yakni: pembelajaran dengan permainan Domat pada Kompetensi Dasar "Melakukan Operasi Hitung Campuran" digunakan oleh peneliti untuk dipertahankan dan dikembangkan. Sebaliknya kelemahan yang muncul dari pembelajaran tersebut di atas, digunakan oleh peneliti sebagai bahan refleksi dan upaya perbaikan pada pertemuan berikutnya. Paparan hasil refleksi dapat dijabarkan sebagai berikut:

1). Partisipasi sisen saat pembelajaran dengan permaian Domat meningkat jika dibandingkan pada siklus satu.

2). Siswa semakin termotivasi untuk berbicara dan menjelaskan kartu yang dipegang dengan menggunakan operasi 
hitung; Perkalian, Pembagian, Penjumlahan, dan Pengurangan

3). Siswa nampak bergembira selama mengikuti pembelajaran. Kegembiraan ini berdampak kepada semangat belajar siswa, sehingga hasil postesnya meningkat dari siklus 1 (rata-rata pretes 79,5 meningkat menjadi rata - rata postes 82,5 ).

4). Upaya peneliti memfasilitasi berlangsungnya PTK cukup bagus. Hal ini nampak dari alat-alat yang tersedia selama berlangsungnya tindakan (ada laptop, LCD, Kartu Domat)

5). Guru sebagai peneliti telah berusaha memperbaiki kinerjanya

6). Guru sebagai peneliti telah berupaya memberi motivasi yang cukup bermakna bagi siswa.

9). Peneliti selalu mengadakan diskusi dengan para observer di akhir pembelajaran pada setiap pertemuan.

Berdasarkan analisa data dan kegiatan pembelajaran selama pelaksanaan PTK siklus dua (2) maka dapat disimpulkan bahwa Permainan Domat sebagai upaya meningkatkan motivasi belajar belajara siswa pada kompetensi dasar "melakukan operasi hitung bilangan campuran" meningkat, sehingga adanya upaya meningkatkan lagi motivasi belajar siswa melalui permainan Domat.

\section{Pembahasan}

\section{Perolehan Proses Belajar}

a. Keberhasilan aktivitas siswa dalam hal penguasaan konsep perkalian, pembagian, penjumlahan dan pengurangan, selama proses pembelajaran melalui permainan Domat pada setiap siklus telah menunjukkan hasil yang signifikan.

b. Aktivitas Siswa Berupa Keterampilan Kognitif, Psikomotorik, dan Afektif selama kegiatan berlangsung mengalami peningkatan khususnya peningkatan kemampuan menjelaskan hasil operasi hitung dari setiap kartu yang dipegang.

Berdasarkan pengamatan peneliti selama berlangsungnya pembelajaran dan hasil wawancara dengan siswa, perkembangan keterampilan kognitif, psiko-motorik, dan afektif yang dialami siswa dalam pembelajaran matematika melalui permainan Domat pada kompetensi dasar "Melakukan Operasi Hitung Campuran" pada siswa kelas III SDN 240 Harue Kecamatan Bulukumpa Kabupaten Bulukumba akibat pemberian tindakan pada siklus I dan siklus II sebagai berikut:

- Siswa merasa senang melaksanakan tugas dalam pembelajaran dengan permainan Domat tentang penguasaan konsep Perkalian, Pembagian, Penjumlahan, dan Pengurangan.

- Siswa meningkat kemampuannya di dalam menjelaskan, khususnya dalam hal keberanian menyampaikan pendapat, menghargai pendapat orang lain dan penguasaan pemahaman dasar konsep matematika.

- Siswa lebih menyadari bahwa pembelajaran dengan permainan Domat memiliki hasil yang lebih besar dari pada pembelajaran yang hanya dilaksanakan dengan ceramah.

- Siswa lebih menyadari bahwa pembelajaran dengan melaksanakan langsung proses penggunaan operasi hitung melalui permainan Domat dianggap lebih tepat guna.

- Ada peningkatan kemampuan siswa dalam mengkonstruksi sendiri berdasarkan pengetahuannya sendiri, melalui permaian Domat.

- Siswa lebih memiliki keberanian dalam melakukan upaya pemahaman tentang operasi hitung.

- Ada keinginan peneliti untuk menerapkan model permaian Domat dalam penguasaan konsep dasar matematika dengan materi yang lain yang relepan.

Tabel 6. Hasil Evaluasi Sebelum Perbaikan Pembelajaran

\begin{tabular}{ccc}
\hline No & Rentang Nilai & Jumlah Siswa \\
\hline 1 & $45-54$ & 3 \\
\hline 2 & $55-64$ & 5 \\
\hline 3 & $65-74$ & 3 \\
\hline 4 & $75-84$ & \\
\hline & Jumlah & 11 \\
\hline
\end{tabular}

Dari tabel hasil evaluasi sebelum perbaikan pembelajaran dapat dilihat bahwa siswa yang mencapai nilai $65-74$ ada 3 siswa atau $27,27 \%$ dari 11 siswa. Sedang 5 siswa atau 
45,45\% mendapatkan nilai 55-64, dan terdapat 3 siswa atau 27,27\% dengan nilai antara 45-54. Hasil evaluasi sebelum perbaikan pembelajaran dalam bentuk grafik dapat disajikan dalam diagram di bawah ini:

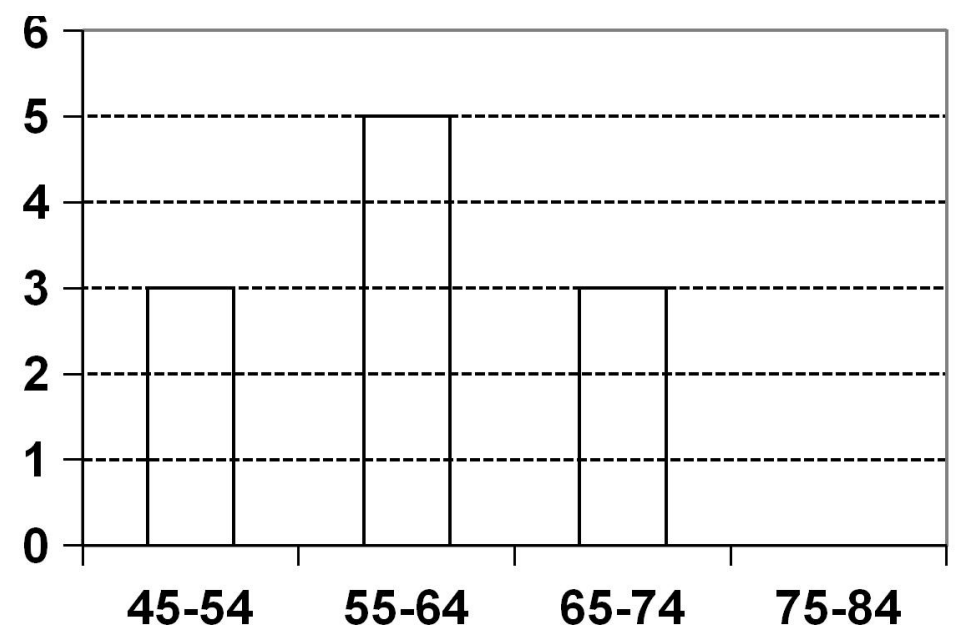

Grafik 1. Hasil Evaluasi Sebelum Pe rbaikan Pembelajaran

Adapaun hasil perolehan data siklus I disajikan dalam tabel di bawah ini:

Tabel 7. Hasil perbaikan siklus I

\begin{tabular}{ccc}
\hline No & Rentang Nilai & Jumlah Siswa \\
\hline 1 & $45-54$ & 2 \\
\hline 2 & $55-64$ & 4 \\
\hline 3 & $65-74$ & 4 \\
\hline 4 & $75-$ keatas & 1 \\
\hline & Jumlah & 11 \\
\hline
\end{tabular}

Dari tabel hasil evaluasi pada perbaikan pembelajaran siklus I dapat dilihat bahwa siswa yang mencapai nilai ketuntasan 75 ke atas ada 1 siswa atau 9,09\% dari 11 siswa.
Siswa yang mendapat nilai antara $65-74$ yakni 4 orang $36,36 \%$.

Hasil evaluasi pada siklus I dalam bentuk grafik dapat disajikan dalam diagram di bawah ini :

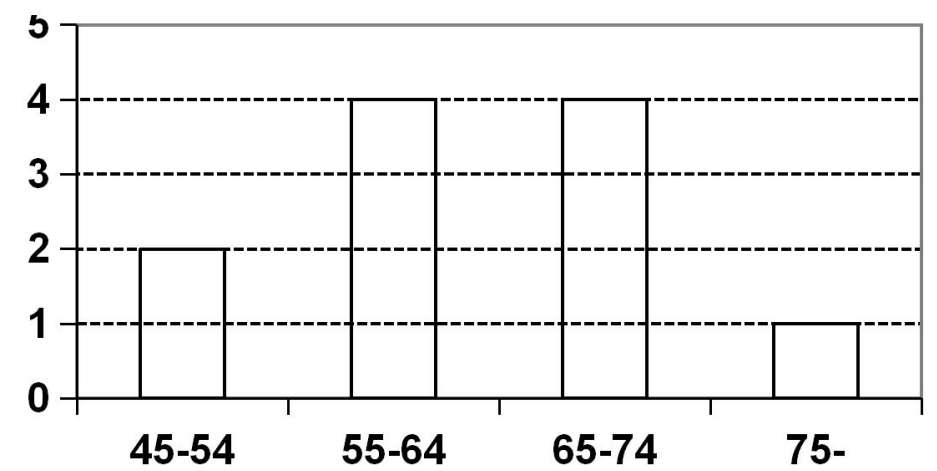

Gambar 2. Hasil Perbaikan Siklus I 
Adapun hasil perbaikan yang didapatkan pada siklus II adalah sebagai berikut:

Tabel 8. Hasil Perbaikan Siklus II

\begin{tabular}{ccc}
\hline No & Rentang Nilai & Jumlah Siswa \\
\hline 1 & $45-54$ & - \\
\hline 2 & $55-64$ & 3 \\
\hline 3 & $65-74$ & 5 \\
\hline 4 & $75-$ keatas & 3 \\
\hline & Jumlah & 11 \\
\hline
\end{tabular}

Dari tabel hasil evaluasi pada perbaikan pembelajaran siklus 2 dapat dilihat bahwa siswa yang mencapai nilai ketuntasan 75 ke atas ada 3 siswa atau $27,27 \%$ dari 11 siswa. Siswa yang mendapat nilai antara 65-74 yakni 5 orang $45,45 \%$. Adapaun hasil evaluasi hasil belajar pada siklus II dapat dijelaskan pada grafik di bawah ini :

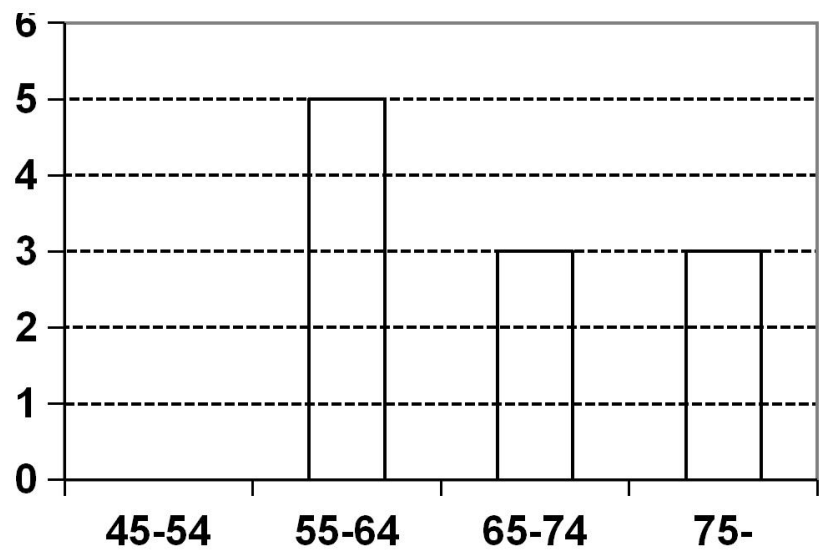

Grafik 3. Hasil Evaluasi Belajar Siklus II

\section{KESIMPULAN \& SARAN}

Berdasarkan semua uraian di atas, khususnya uraian pada bab IV peneliti menyampaikan kesimpulan sebagai berikut :

1. Pembelajaran matematika pada Kompetensi dasar Melakukan Operasi Hitung Campuran pada siswa kelas III SDN 240 Harue Kecamatan Bulukumpa Kabupaten Bulukumba, melalui permainan Domat dapat meningkatkan motivasi dan prestasi belajar siswa.

2. Pelaksanaan pembelajaran dengan menggunakan media kartu Domino telah mengakibatkan siswa lebih termotivasi untuk aktif dalam pembelajaran.

3. Pembelajaran dengan penguasaan konsep dasar metematika melalui permaian Domat merupakan pembelajaran yang menyenangkan bagi siswa kelas III SDN 240 Harue Kecamatan Bulukumpa Kabupaten Bulukumba.

4. Pembelajaran dengan menggunakan media kartu Domino tentang pemahaman konsep dasar matematika telah membentuk siswa untuk lebih aktif, kreatif, inovatif, mandiri dan bekerjasama, serta lebih termotivasi untuk belajar.

\section{Saran}

Mengacu kepada kesimpulan di atas, maka peneliti menyampaikan saran sebagai berikut:

1. Supaya pembelajaran ini dapat digunakan sebagai alternatif pembelajaran dalam penanaman konsep dasar matematika bagi siswa kelas awal di sekolah dasar.

2. Dalam penelitian ini, kemampuan argumentasi siswa mulai muncul namun belum optimal, maka perlu dikembangkan dengan metode atau media pembelajaran yang lain.

3. Peneliti juga memberikan rekomendasi kepada peneliti lain untuk mengembangkan peramainan Domat pada pembelajaran matematika yang dipadukan dengan metode-metode pembelajaran lain.

\section{DAFTAR PUSTAKA}

Ali Imron,1996. Belajar dan Pembelajaran. Jakarta: Pustaka Jaya.

Gunartono. 2003. Strategi Belajar Mengajar. Jakarta: Penerbit Rineka Cipta.

H. Din Wahyudin. 2001. Pengantar Pendidikan IPA. Jakarta: Pusat Penerbitan Universitas Terbuka. 
Mulyani, Sumantri, dkk. 2001. Strategi Belajar Mengajar. Bandung: CV. Maulana.

Pelatih TIM Sekolah, Jum. 2007. Apa dan Mengapa Pembelajaran Tematik. Semarang.

Prasetyo T.2004. Hubungan konsep diri dan kecemasan siswa dengan prestesi belajar IPA pada siswa SD yang diajar dengan pola SEQIP di Kecamatan Tingkir Kota Salatiga. Universitas Kristen Satya Wacana Salatiga

Rostina Sundayana, 2015. Media dan Alat peraga dalam Pembelajaran Matematika.Bandung: Alfabeta.

Soedjadi, 2007 Masalah kontekstual Sebagai Batu Sendin Matematika Sekolah Dasar. Surabaya: Pusat Sains dan matematika Sekolah

Slameto. 2003. Belajar Dan Faktor-faktor yang Mempengaruhinya. Yakarta: Rineka Cipta

Suhardjono, 2009. Pertanyaan dan Jawaban di Sekitar Penelitian Tindakan Kelas dan Tindakan Sekolah, Penerbit Cakrawala Indonesia (LP3 Universitas Negeri Malang)

Wardani, I.G.A.K. dkk. 2002. Penelitian Tindakan Kelas. Jakarta: Pusat Penerbitan Universitas Terbuka. 